\title{
RANBP2-ALK 急性骨髄性白血病に対するクリゾチニブの治療効果と耐性メカニズム
}

竹岡加陽 ${ }^{1 *}$, 奥村敦子 ${ }^{1}$, 岸森千幸 ${ }^{2}$, 本庄 原 $^{3}$, 和泉清隆 ${ }^{4}$, 前迫善智 ${ }^{4}$, 赤坂尚司 ${ }^{4}$, 大野仁嗣 1,4

1 天理よろづ相談所 医学研究所

2 天理よろづ相談所病院 臨床検査部

3 天理よろづ相談所病院 病理診断部

4 天理よろづ相談所病院 血液内科

症例：初診時 75 歳女性. 入院 2 週間前に上気道炎症状のため当院を受診，血液検査で白血球増多を認めたた め血液内科を紹介受診した. 白血球数 $143.6 \times 10^{3} / \mu \mathrm{L}$ (単球 $38.6 \%$ ，芽球 $2.6 \%$ ），LDH 2,279 IU/L. 核型は， G-banding と $A L K$ break-apart probe を用いた FISH で 45,XX,inv(2)(p23q13), - 7. RT-PCR でRANBP2-ALK fusion mRNA を検出し，PCR 産物のシークエンシングでRANBP2 exon 18 と ALK exon 20 の接合を認めた. ALK の免疫 染色では，白血病細胞の核膜が染色された.

治療経過 : 通常の寛解導入療法とアザシチジンが奏効したが，治療開始 10 か月後に再発した. 患者本人のイン フォームドコンセントと，当院の倫理委員会の承認を得て，クリゾチニブ ( $250 \mathrm{mg} \mathrm{BID)}$ の投与を開始した. 白血 病細胞は速やかに減少し，一旦完全寛解の診断基準に到達したが，day 135 に再発した. 再発時の白血病細胞から DNA とRNA を抽出し，ALK のキナーゼドメインの遺伝子变異を検索したところ，exon 25 に c.3806G>C/p.G1269A 変異を認めた. 染色体分析では，新たに del(1)(p13p22) が認められた.

考案 : クリゾチニブは，RANBP2-ALK 急性骨髄性白血病に対して高い抗腫瘍効果を示し，正常造血も回復したが， 奏効期間は短期間であった. 本剂単独では長期の寛解を維持することは困難であるので，通常の化学療法薬と併 用する必要があると考えられた.

キーワード:RANBP2-ALK，急性骨髄性白血病，クリゾチニブ，G1269A 変異

\section{緒言}

$A L K$ (anaplastic lymphoma kinase) 遺伝子は, 染色 体転座・逆位によって多様なパートナー遺伝子と 再構成し, 腫瘍特異的なキメラ蛋白をコードする. キメラ蛋白は二量体を形成し, ALK キナーゼドメ インが活性化する。その結果, 下流のシグナル伝

*連絡先 : 竹岡加陽

干 632-8552 天理市三島町 200

天理よろづ相談所 医学研究所

e-mail: takeoka@tenriyorozu.jp
達が恒常的に活性化し腫瘍発生に至ると考えられ ている.この研究成果に基づいて, ALK 蛋白を標 的とした分子標的治療薬が開発されている. ${ }^{1}$ クリ ゾチニブ（商品名：ザーコリ）は，低分子チロシ ンキナーゼ阻害薬で, $A L K$ 再構成陽性の非小細胞 肺癌に承認されている。昨年我々は, $A L K$ 再構成 陽性の急性骨髄性白血病 (AML) 症例を報告した。2 今回は，本症例に対してクリゾチニブを投与した のでその経過を報告する。 
症例

初診時 75 歳の女性. 主訴は発熱と咳嗽. 入院 2 週間前に上気道炎症状を認め, 総合感冒薬で改善 しないため, 当院総合内科を受診した。血液検査 で顕著な白血球増多を認めたため，血液内科紹介 となった。血球検査では, 大球性貧血と血小板減 少を認め, 白血球数は $143.6 \times 10^{3} / \mu \mathrm{L}$ ，分画では 単球が $38.6 \%$ を占め, 芽球も認めた。 LDH は 2,279 IU/L であった。骨髄は過形成で, 芽球 $32.1 \%$, 単 球 $14.6 \%$ であった。芽球は中型で N/C が高く，核 は類円形〜馬蹄形，核網は繊細，核小体は不明瞭， 背景に単球の増加も伴っていた. Peroxidase 染色 では，芽球の $51.5 \%$ が陽性であった。その他の所 見として, 好中球顆粒出現不良や偽 Pelger 核異常, Dohle 小体を認め, 二核, 三核の巨大な異型細胞も 認めた。以上から，慢性骨髄単球性白血病から転 化した AML と診断した。 ${ }^{2}$

染色体分析では, G-banding と ALK break-apart probe を用いた分裂核 FISH で $\operatorname{inv}(2)(\mathrm{p} 23 \mathrm{q} 13)$ が認 められ，核型は 45,XX,inv(2)(p23q13),-7 であった。 骨髄スメア標本を用いた間期核 FISH でも，ALK 遺 伝子の再構成と monosomy 7 が確認された。inv(2) (p23q13)の ALK のパートナー遺伝子は，2q13 に位 置する RANBP2 遺伝子であることが報告されてい
たので，骨髄から RNA を抽出し，RANBP2 と $A L K$ のプライマーを設定しRT-PCR を行った。その結 果，RANBP2-ALK 融合 mRNA を認め, PCR 産物の シークエンシングによって, RANBP2 exon 18 と $A L K$ exon 20 の接合が明らかになった。一方，骨髄生検 標本の ALK 蛋白の免疫染色では, 白血病細胞の核 膜が染色された。以上の結果から，RANBP2-ALK AML と診断した.2

\section{治療経過}

AML の標準治療であるダウノルビシンーシタラビ ンレジメンによって一旦寛解状態となったが 1 か月 後に再発した (1st relapse). アザシチジンが奏効し たが，治療開始から 10 か月後に再々発した（2nd relapse）（図 1)。骨髄では，芽球 $21.0 \%$ ，骨髄 3 系 統に初診時と同様の細胞異型を認めた（図 $2 \mathrm{a}, \mathrm{b}$ ). FISH では， $80 \%$ 以上の細胞が $A L K$ 再構成陽性で あった。

患者本人と家族の書面による同意と, 当院の倫 理委員会の承認を得た上で，ALK チロシンキナー ゼ阻害剤であるクリゾチニブの投与を開始した。 規定量の $250 \mathrm{mg}$ BID の投与によって末梢血中の芽 球は速やかに減少したが，好中球数も 0 となった ため, いったん減量・休薬し，G-CSF を併用しな
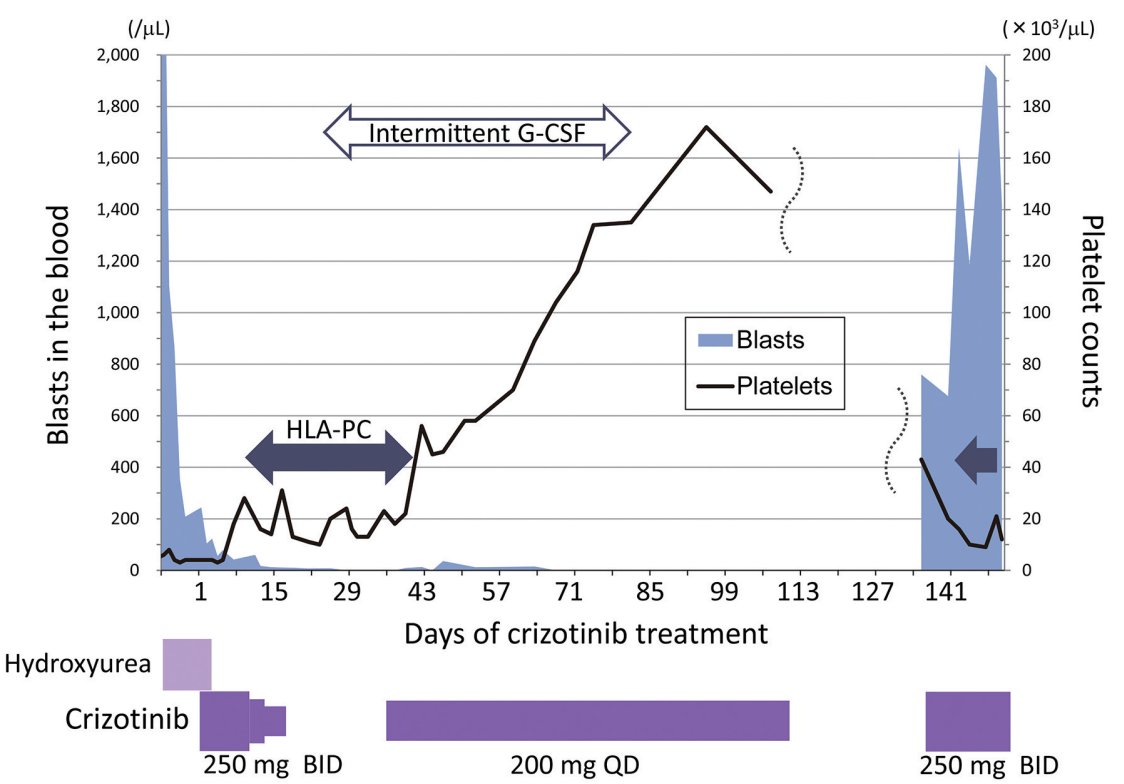

図 1. クリゾチニブ投与後の治療経過

横軸にクリゾチニブ治療後の日数, 左 軸に末梢血中の芽球数, 右軸に血小板 数を示す. 2nd relapse に対してクリゾチ ニブ $250 \mathrm{mg}$ BIDを開始したところ，末 梢血中の芽球は劇的に減少した. しか し，好中球数も 0 となったため，いった ん減量・休薬し, G-CSF を併用しなが ら $200 \mathrm{mg}$ QD で再開した. その結果, 芽球は完全に消失し, 血小板は徐々に 増加した. しかし, day 135 に芽球が末 梢血中に再び出現した (3rd relapse). ク リゾチニブを $250 \mathrm{mg}$ BID に増量したが, 抗腫瘍効果は認めなかった . 

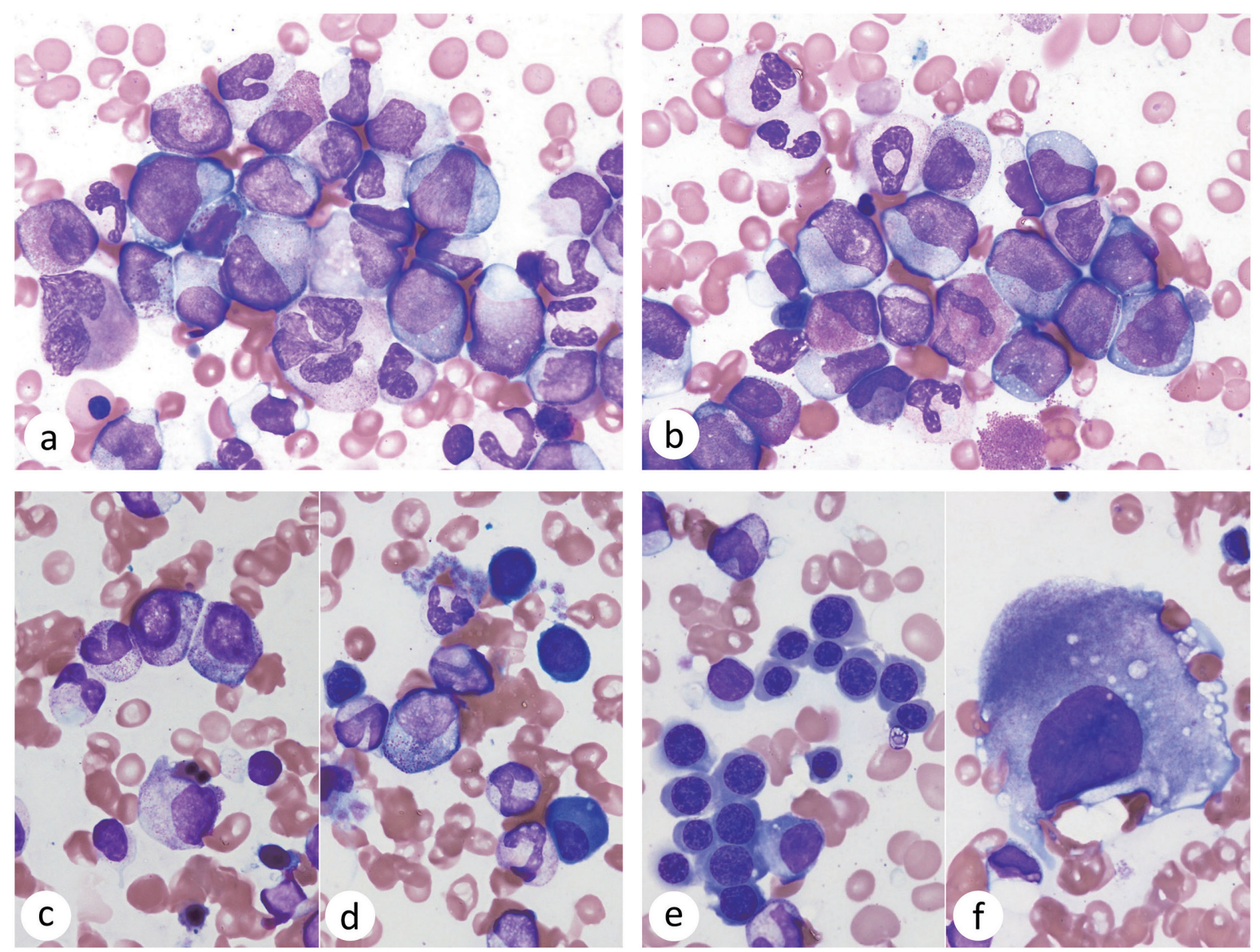

図 2. 骨髄像（Wright 染色，対物レンズ × 100）

a, b : クリゾチニブ治療前 (2nd relapse). 芽球, 偽 Pelger 核異常, 好中球顆粒出現不良, 巨大好中球を認める.

$c \sim f:$ クリゾチニブ治療後. 芽球は $1.4 \%$ に減少し, 正常造血が回復したことから, AML の完全寛解の診断基準に到達した. c, d: 骨髄球, 正常好中球, e : 赤芽球島, $f$ : 巨核球.

がら $200 \mathrm{mg}$ QD で再開した（図 1)。Day 82 には, 骨髄中の芽球は $1.4 \%$, FISH による $A L K$ 再構成陽 性細胞もカットオフ值以下に減少した。正常造血 も回復し, AML の完全寛解の診断基準に到達した (図 2c f). しかし, 外来で経過観察していたところ, day 135 に再発した (3rd relapse). クリゾチニブを $250 \mathrm{mg}$ BID に増量したが, 抗腫瘍効果は認めなかっ た（図 1). Day 135 の骨髄検查では, 白血病細胞 は未分化な形態を示し (図 3a, b), FISH では, 再び, 約 $80 \%$ の細胞が $A L K$ 再構成陽性, monosomy 7 陽 性を示した（図 3c，d）.さらに, 染色体分析では, 従来認めた $\operatorname{inv}(2)(\mathrm{p} 23 \mathrm{q} 13)$ と -7 に加えて, 新たに 1 番染色体短腕の欠失 $\operatorname{del}(1)(\mathrm{p} 13 \mathrm{p} 22)$ が認められた。

\section{クリゾチニブの耐性メカニズム}

クリゾチニブの耐性メカニズムの一つとして, ALK のキナーゼドメインの遺伝子変異が明らかに されている，そこで，クリゾチニブ治療前と治療 後再発時 (3rd relapse) の骨髄から DNA と RNAを 抽出し, キナーゼドメインに該当するエクソンを 全て PCR 増幅・シークエンシングし , ${ }^{1,3,4}$ 変異の 有無を検索した。その結果, $A L K$ exon 25 の c.3806G (mRNA では reference sequence NM_004304.4の 4,758 番目の G, DNA では reference sequence NG_009445.1の716,751番目の G）が C に変異し ていた (c.3806G $>$ C) (図 4). ゲノム PCR と RTPCR の塩基配列を比較すると，DNAレベルでは $\mathrm{G}$ と $\mathrm{C}$ が混在したへテロの状態であったのに対 

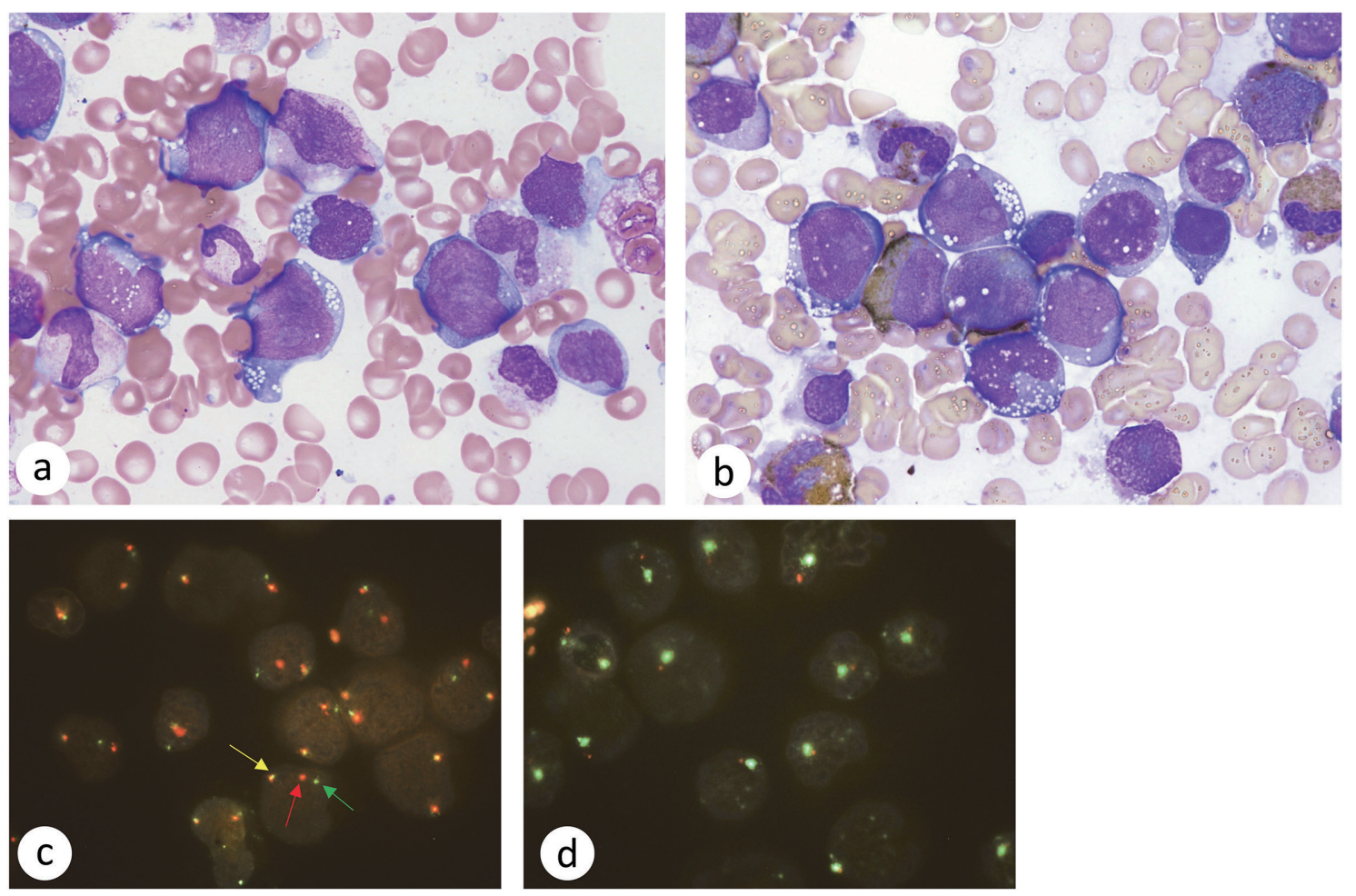

図 3. クリゾチニブ投与後の再発時 (3rd relapse) の骨髄像と FISH (day 135)

$a, b$ : 芽球はクリゾチニブ投与前よりさらに未分化な形態を示した（a, Wright 染色； b, ペルオキシダーゼ染色. 対物レンズ $\times 100)$.

c：約 80\% の細胞が $A L K$ 再構成陽性である. 矢印は, 再構成陽性を示す赤 1 緑 1 黄 1 のシグナルパターンを示している.

$\mathrm{d}$ : 約 $80 \%$ の細胞に 7 番染色体の欠失 (monosomy 7) を認めた.

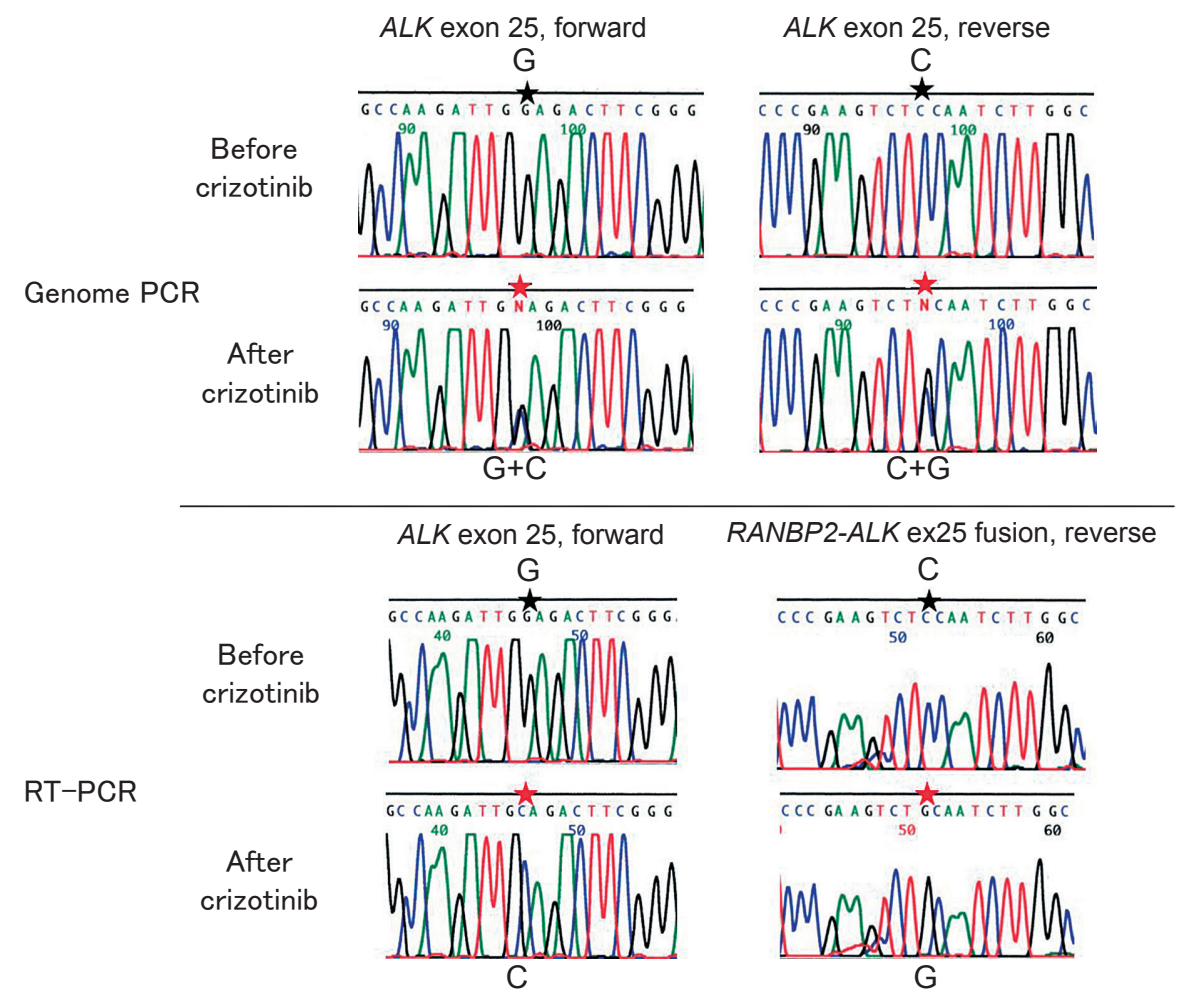

図 4. ALK キナーゼドメインに生 じた点突然変異

上段が DNAレベル（ゲノム $\mathrm{PCR})$ ，下段が RNAレベル (RT$\mathrm{PCR})$ の塩基配列を示す. $A L K$ exon 25 の 1 塩基が, $\mathrm{G}$ から C に 変異している. DNAレベルでは, 正常の G と異常の C が混在した ヘテロの状態であるが, RNAレベ ルでは，変異した C が選択的に 転写されていた. 


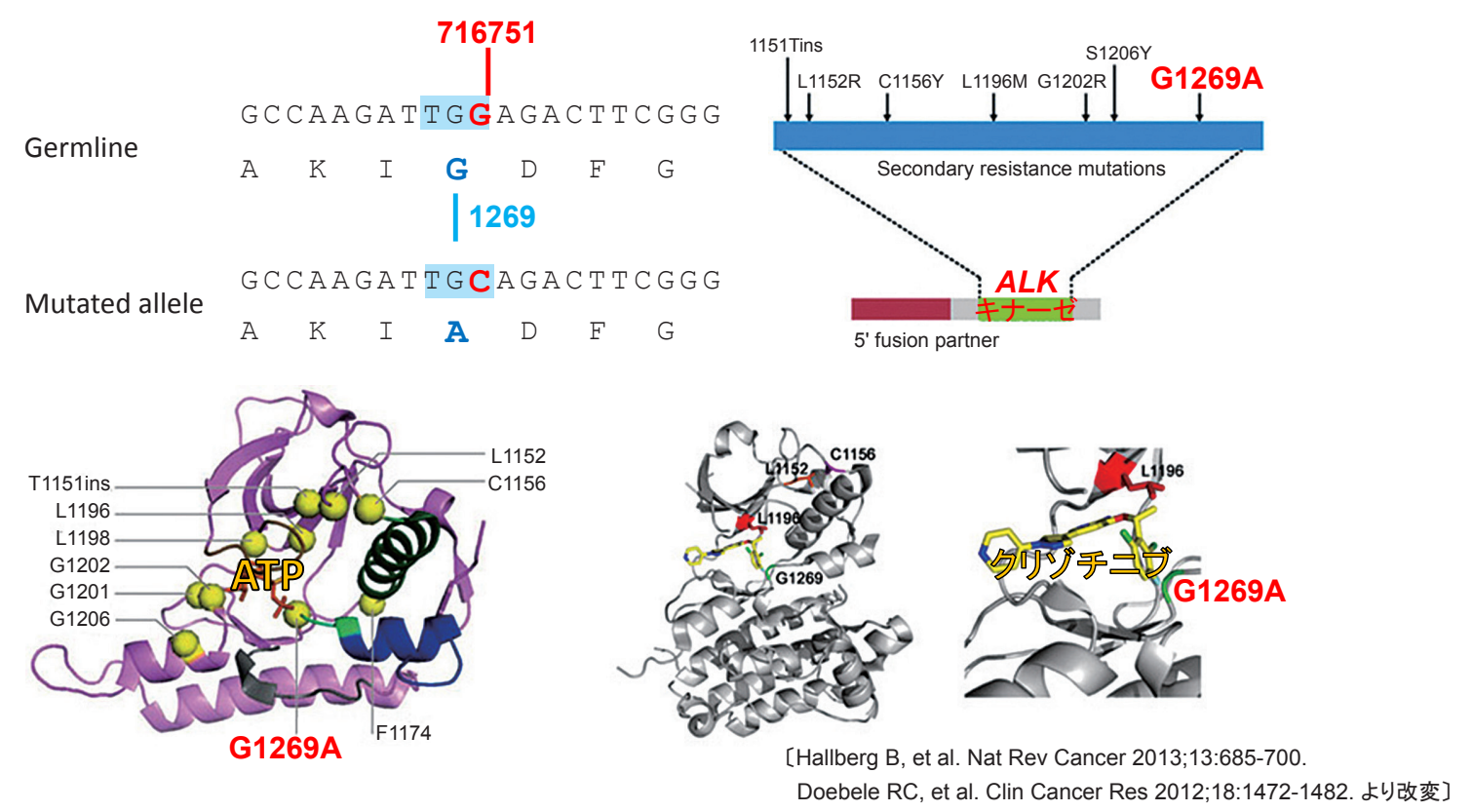

図 5. ALK キナーゼドメインの G1269A 変異

図 4 に示した 1 塩基変異によって，アミノ酸レベルでは，1269 番目のグリシンがアラニンに変化する．この変異部分は，ATP の結合 部位に当たり，かつ，クリゾチニブが結合する部位に該当する。

し, mRNA レベルでは, 変異した C のみが選択 的に転写されていた（図4).アミノ酸レベルで は，c.3806G>C 変異によって, ALK 蛋白の 1,269 番目のグリシンがアラニンに変化することになる (p.G1269A)（図 5)。この変異が原因で，ALK 蛋白 の三次構造が変化し，クリゾチニブが反応できな くなったと考えられた（図 5） 5,6.

\section{結語}

再発・治療抵抗性の RANBP2-ALK AML に対して クリゾチニブを投与したところ，短期間の血液学 的寛解を得ることができたが， day 135 に再発した (3rd relapse). クリゾチニブ治療後に新たに生じた $\operatorname{del}(1)(p 13 p 22)$ と, ALK のキナーゼドメインの変異 c.3806G >C /p.G1269A がクリゾチニブの耐性化に関 与したと考えられた. クリゾチニブ単独では長期 の寛解を維持することは困難であるので，通常の 化学療法薬と併用する必要があると考えられた。

\section{参考文献}

1. Chen Y, Takita J, Choi YL, et al. Oncogenic mutations of ALK kinase in neuroblastoma. Nature 2008;455:971-974.

2. Maesako Y, Izumi K, Okamori S, et al. inv(2)(p23q13)/ RAN-binding protein 2 (RANBP2)-ALK fusion gene in myeloid leukemia that developed in an elderly woman. Int J Hematol 2014;99:202-207.

3. Dirks WG, Fahnrich S, Lis Y, et al. Expression and functional analysis of the anaplastic lymphoma kinase (ALK) gene in tumor cell lines. Int J Cancer 2002;100:49-56.

4. Ma Z, Hill DA, Collins MH, et al. Fusion of $A L K$ to the Ran-binding protein 2 (RANBP2) gene in inflammatory myofibroblastic tumor. Genes Chromosomes Cancer 2003;37:98-105.

5. Hallberg B, Palmer RH. Mechanistic insight into ALK receptor tyrosine kinase in human cancer biology. Nat Rev Cancer 2013;13:685-700.

6. Doebele RC, Pilling AB, Aisner DL, et al. Mechanisms of resistance to crizotinib in patients with $A L K$ gene rearranged non-small cell lung cancer. Clin Cancer Res 2012;18:1472-1482. 


\title{
Treatment of acute myeloid leukemia carrying inv(2)(p23q13)/RANBP2-ALK with crizotinib and the mechanism of resistance to the drug
}

\author{
Kayo Takeoka ${ }^{1}$, Atsuko Okumura ${ }^{1}$, Chiyuki Kishimori ${ }^{2}$, Gen Honjo ${ }^{3}$, Kiyotaka Izumi, ${ }^{4}$ Yoshitomo \\ Maesako, ${ }^{4}$ Takashi Akasaka, ${ }^{4}$ Hitoshi Ohno ${ }^{1,4}$ \\ ${ }^{1}$ Tenri Institute of Medical Research; ${ }^{2}$ Department of Laboratory Medicine, Tenri Hospital; ${ }^{3}$ Department of Diagnostic \\ Pathology, Tenri Hospital; ${ }^{4}$ Department of Hematology, Tenri Hospital
}

A 75-year-old woman with acute myeloid leukemia (AML), who carried the inv(2)(p23q13)/RANBP2$A L K$ fusion gene and monosomy 7 and exhibited nuclear membrane expression of ALK protein, showed florid relapse of AML. Fluorescence in situ hybridization (FISH) of a bone marrow smear slide using an ALK break-apart probe revealed that over $80 \%$ of the cells had $A L K$ rearrangement. We obtained her written consent and treated her with crizotinib, an inhibitor of ALK tyrosine kinase. Leukemia cells in the blood rapidly disappeared and $A L K$ rearrangement-positive cells identified by FISH in the bone marrow decreased below the cut-off level. The response at 3 months of crizotinib treatment was comparable to the definition of complete remission (CR) of AML. On day 135 of treatment, however, her AML relapsed. G-banded karyotyping revealed del(1)(p13p22) in addition to inv(2) and -7 after crizotinib. The $A L K$ gene carried the heterozygous mutation c.3806G $>C$ within exon 25, causing p.G1269A amino acid substitution within the kinase domain of ALK. As both del(1)(p13p22) at the cytogenetic level and G1269A at the nucleotide level newly appeared after crizotinib treatment, it is likely that they were secondarily acquired alterations involved in crizotinib resistance. Although the initial response to crizotinib was marked, crizotinib alone was not capable of producing a long-term response. We should have performed consolidating chemotherapy using conventional cytotoxic drugs immediately after the achievement of $\mathrm{CR}$ by crizotinib.

Keywords: AML with inv(2)(p23q13)/RANBP2-ALK, crizotinib, G1269A mutation 